\title{
Ngā tapuwae o mua mō muri: Footprints of the past to motivate today's diverse learners
}

\author{
Angus Hikairo Macfarlane \\ College of Education \\ University of Canterbury
}

\begin{abstract}
The contention that diversity in education is in the global arena and considered the norm is a relatively recent phenomenon. Pockets of consciousness about culturally responsive pedagogies have developed over time and the movement toward an equitable positionality for minoritised learners has been liberating of many indigenous societies' aspirations. It is not, however, without challenges. This paper sets out to describe a selection of 'classic' studies from the 1990s, and to discuss some key imperatives that rationalise their durability over time, and their relevance in the present. Attention is then turned toward research and policies related to the provision of Mäori students' education generated in Aotearoa New Zealand during the past two decades. The paper concludes by reporting on a unique iwi-based (tribe-based) research project embedded in iwitanga (tribal protocols) while simultaneously nested within te ao Māori: the Māori world. This project sheds light on the reasons for some Māori secondary students' educational success, and suggests that the characteristics these students share will continue to bring them success in the future.
\end{abstract}

\section{Keywords}

Māori, success, diversity

\section{Introduction}

Communities worldwide are acknowledging the fact that diversity in education is not a possibility but a reality; it is no longer the exception-it is now the norm (Au, 1998; Graybill, 1997; Green \& Cherrington, 2010; Ladson-Billings, 1995; Smith, 2009). In localised Aotearoa New Zealand contexts, Māori learners need access to teachers and school leaders who have the prerequisite skills that enable culturally responsive interactions to transpire-interactions that will motivate Māori learners to realise their own potential. Culturally responsive interactions encompass educators' attitudes, expectations, contextual climate, relevant content, and the pedagogical approaches that emanate within schools and classrooms. More significantly it requires educators to remain cognisant of diversity as it applies to, and within, te ao Māori (the Māori world; a Māori worldview) in the unique and diverse localised settings that exist in this country (Cavanagh, Macfarlane, Glynn, \& Macfarlane, 2012; Glynn, Wearmouth, \& Berryman, 2005; Hattie, 2003; A. Macfarlane, 2007; A. H. Macfarlane, Webber, Cookson-Cox, \& McRae, 2014; Parsons, 2012). In this sense, intercultural relationships are foundational to ensuring that culturally safe and relevant learning environments (those that accept and celebrate diversity) and culturally responsive pedagogies are seen, heard and felt.

Wilf Malcolm Institute of Educational Research, Faculty of Education, University of Waikato, Hamilton, New Zealand ISSN: 2382-0373

(pp. 27-38)

Author Contact: Angus Macfarlane angus.macfarlane@canterbury.ac.nz 
This paper will paint a landscape that illuminates a range of culturally responsive school contexts that successfully motivate and enable diverse learners to achieve. The first (an international panorama) will report on some of the North American classic studies; the second (a national view) will explore some studies and programmes in Aotearoa New Zealand that are specifically focussed on Māori learners; and the third (a localised setting) will showcase a Te Arawa-specific secondary schools iwi-based project - one that is founded on the shared ideology of a community of Te Arawa educators who engage in reciprocity within their iwi by way of research-related activities. This unique project unpacks the challenges and opportunities that arise for Māori learners as they aspire to educational success. A set of key concepts that are iwi-specific are identified as cultural enablers for achieving their educational aspirations.

\section{North American Classic studies}

Research in the areas of culturally responsive teaching is broadening our understanding of the teacher's impact on students' motivation, learning and academic success. Teachers' attitudes, expectations and approaches to classroom management influence classroom climate, shape what is taught, determine how teaching is orchestrated, and have a significant impact on student achievement (Darling-Hammond, 2010; Eisner, 1994; Franklin, 1998; Graybill, 1997; Pierce, 1996). Students' cultural backgrounds need to be at the centre of teaching and learning, and successful educators acknowledge, respect and build on the beliefs and experiences that students bring to classrooms. By way of affirming and valuing students' cultural backgrounds, culturally responsive teachers can make a huge difference to their educational outcomes. The following 1990s North American 'classic' studies by Grace Stanford and Gloria Ladson Billings reiterate these claims and provide examples of culturally responsive teaching.

Stanford's (1997) case studies of exemplary, award-winning teachers resonated with other studies of the time, such as those of Gloria Ladson-Billings and Cecilia Pierce. It became clear that culturally responsive teachers created a sense of community in their classrooms, sometimes assuming a familial role in addition to the teacher position. The classes were often referred to as being "like a family" (Stanford, 1997, p. 113), serving as a magnet for students. One student commented on the fact that students "want to be here [in the classroom]" because it was considered a safe haven with a presence of "the human touch" (Stanford, 1997, p. 113). One teacher stated, "I teach children, not subject matter" (Stanford, 1997, p. 113).

All teachers in the study expected students to meet high academic and behavioural standards, but their interest in students was not limited to their cognitive development. They were also concerned about their students' social and emotional growth. Teachers' interest in the whole child was manifested in a range of different ways; for example, sharing the teacher's life experiences, and extending students' education beyond the classroom. Another common theme was the teachers' willingness to accept responsibility for teaching their students, even though they confronted challenging situations that frequently created despair and inertia among their less effective colleagues. Rather than wasting time complaining about inadequate resources, the teachers frequently used their own money to provide needed material. Further, none of the teachers apportioned blame to the students for experiencing academic and social difficulties. Neither did they speak disparagingly of their home environments. Students were accepted for who they were and teachers sought ways to build on their strengths, creating a classroom environment which nurtured sustained learning. The teachers derived satisfaction from their students' successes; for example, one teacher stated that when a student is "blossoming out" it just "does something to me" (Stanford, 1997, p. 116). Stanford suggested that the success of these teachers replicated the findings of Ladson-Billings' (1995) classic studies on effective AfricanAmerican pedagogy.

Further, Ladson-Billings (1995) proposed the development of a sociocultural model that not only addressed student achievement but also accepted and affirmed students' cultural identity. A strong cultural identity was needed for them to develop the critical perspectives to challenge inequities that schools (and other institutions) perpetuate. Ladson-Billings (1995) termed this pedagogy "culturally relevant pedagogy" (p. 469) - teaching that draws on the students' culture to achieve academic success and excellence without students losing their sense of personal and cultural identity. There 
were four phases to this study. The first consisted of an ethnographic interview to discuss teacher background, teaching philosophy, and notions about curriculum, classroom management, and parent and community involvement. In the second phase teachers agreed to be observed regularly by the researcher on an unscheduled basis, at an average of three days a week for almost two years. The third phase involved videotaping the teachers in action. The last phase required the teachers to work together as a research collaborative to view segments of each other's videotapes. In a series of 10 two to three hour meetings, the teachers participated in analyses and interpretations of their own and colleagues' practice. It was during this stage of the study that formulations about culturally relevant pedagogy that had emerged in the initial interviews were confirmed by practice.

The teachers in the Ladson-Billings study were required to meet a set of teaching criteria, considered essential for supporting their students to be academically successful, culturally competent and sociopolitically critical; provision of concrete experiences as carriers of meaning; use of dialogue in assessing knowledge claims; an ethic of care; an ethic of personal accountability; cultural critique; and cultural competence. However, the teachers met these criteria in different ways, which led LadsonBillings to search for commonalities in their theoretical perspectives that might refine the concept and practice of culturally relevant teaching. Three broad commonalities were demonstrated:

- Conceptions of self and others.

- Conceptions of social relations.

- Conceptions of knowledge.

The chief beliefs and practices which drive the above propositions are outlined in Table 1 below.

Table 1.Commonalities which define culturally relevant teaching

\begin{tabular}{|l|l|l|}
\hline \multicolumn{1}{|c|}{$\begin{array}{c}\text { Conceptions of Self and } \\
\text { Others }\end{array}$} & \multicolumn{1}{|c|}{$\begin{array}{c}\text { Conceptions of Social } \\
\text { Relations }\end{array}$} & \multicolumn{1}{|c|}{ Conceptions of Knowledge } \\
\hline $\begin{array}{l}\text { Saw all students as capable of } \\
\text { academic success. }\end{array}$ & $\begin{array}{l}\text { Maintained smooth student- } \\
\text { teacher relations. }\end{array}$ & $\begin{array}{l}\text { Viewed knowledge as not static } \\
\text { but a dynamic construct to be } \\
\text { shared. }\end{array}$ \\
\hline $\begin{array}{l}\text { Saw their pedagogy as art- } \\
\text { unpredictable always in the } \\
\text { process of becoming. }\end{array}$ & $\begin{array}{l}\text { Demonstrated a connectedness } \\
\text { with all students. }\end{array}$ & $\begin{array}{l}\text { Viewed knowledge as a } \\
\text { phenomenon that is open to } \\
\text { criticality. }\end{array}$ \\
\hline $\begin{array}{l}\text { Saw themselves as members of } \\
\text { the community. }\end{array}$ & $\begin{array}{l}\text { Developed a community of } \\
\text { learners. }\end{array}$ & $\begin{array}{l}\text { Viewed passion for knowledge of } \\
\text { learning as a facilitation of } \\
\text { learning. }\end{array}$ \\
\hline $\begin{array}{l}\text { Saw teaching as a way to give } \\
\text { back to the community. }\end{array}$ & $\begin{array}{l}\text { Encouraged students to learn } \\
\text { collaboratively and be } \\
\text { responsible for one another. }\end{array}$ & $\begin{array}{l}\text { Viewed assessment as a } \\
\text { multifaceted mode. }\end{array}$ \\
\hline
\end{tabular}

Those classic studies of two decades ago, like more recent ones (Brayboy \& Castagno, 2009; Delpit, 2006; Howard, 2003; Sleeter, 2001), show that meeting the needs of minoritised students, their parents and communities must be the overriding priority in terms of equity and best educational practices. Identifying the learning and motivation of students in a culturally relevant manner must also be at the heart of educational philosophies and practices. According to Peer and Reid (2000):

It is necessary that culture-fair principles and practices are considered in the identification and assessment processes, in classrooms practices and provision, the curriculum, in the training of teachers, support assistants and psychologists, in the selection and allocation of resources, in policy and in liaison with parents and the wider community. (p. 1)

Are some things changing in schools? Are teachers teaching differently and learners learning differently? Or are the changes philosophical and are the realities still the same? Now, more than ever, classrooms should be places where the gifts of diversity enable people to learn from each other and 
where the need for unity is basic. Parsons (2012) proclaims that we should be inviting diversity into our willingness to listen and learn together. It is to cultural diversity within the Aotearoa New Zealand educational system that we now turn.

\section{Studies within Aotearoa New Zealand}

In 2006, the polarised achievement of New Zealand students was highlighted in the Programme for International Student Assessment (PISA) study. Despite indicating high levels of achievement in literacy and numeracy for New Zealand students overall (i.e., above the Organisation for Economic Cooperation and Development (OECD) mean), further analysis of the data indicated that Māori students were well below this mean (Telford \& Caygill, 2007). This has become euphemistically described as the long "tail" of disparity (Airini, McNaughton, Langely, \& Sauni, 2007; Hattie, 2003). Why is this still so? Could the disparity be explained (in part) by a systemic failure to redress or respond to the gap between the theoretical statements and teaching practice? Is the disparity ethnically rooted?

In regards to the last two questions, some research in recent years would suggest so. For example, there has been growing concerns about the reasons for the over-representation of referrals of Māori learners to special education behaviour services. A plethora of research indicates that many behaviour referrals for ethnic minority students are made as a result of misinterpretation of particular behaviours by teachers who are from different cultural backgrounds (Medcalf, Rangi, Macfarlane, \& Glynn, 2003; Moore et al., 1999; Peters \& Paki, 2012; Prochnow \& Macfarlane, 2008; Savage et al., 2011; Townsend, 2000). Research also indicates that many teachers fail to understand how their classroom processes and practices are actually detrimental to effective learning for minoritised students (A. Macfarlane, 2007; Nuthall, 1997; Wheldall \& Glynn, 1989; Ysseldyke \& Christensen, 1998). Often they will misinterpret what learning actually 'looks like' (Nuthall, 1997) or explain away an obvious 'lack' of learning as an issue coming from outside the classroom - attributable to family dysfunction and/or student attitude and aptitude (Bishop, Berryman, Cavanagh, \& Teddy, 2007). Such forms of deficit theorising are, according to Prochnow (2006), exacerbated over time by the cyclic nature of cause and effect, which entrenches a classroom culture primarily based on teachers and students 'talking past each other' (Metge \& Kinloch, 1984).

Whether the relevant approach is referred to as 'culturally responsive', 'Māori-preferred', 'placebased', 'culturally infused', or 'bottom-up', a plethora of data is available worldwide to illustrate that when indigenous minority students' culture is acknowledged, and infused in the classroom context and content, it "build[s] a bridge to school success." (Reyhner, cited in Starnes, 2006, p. 384). Over the last decade, studies of culturally linked school programmes have provided ample evidence that such approaches result in increased student participation and learning, more positive behaviour, and improvements in related social and cultural indicators (Bishop \& Berryman, 2006; S. Macfarlane, 2009; Otrel-Cass, Cowie, \& Glynn, 2009;). In 2008, the New Zealand Ministry of Education introduced a strategy to raise Māori achievement, Ka Hikitia: Managing for Success (Ministry of Education, 2008), a welcome response to the clarion call from school and community leaders for purposeful, specific and clearly laid out directives.

\section{Stepping up}

The Ministry of Education's (2008) Māori Education Strategy (Ka Hikitia) challenged the education sector to work with greater urgency in order to make a positive difference for Māori learners. This strategy acknowledged the fact that inequitable education outcomes for Māori have persisted for too many years, and addressing these disparities is now a priority for all those involved in education. $\mathrm{Ka}$ Hikitia literally means "to step up" or "to lengthen one's stride". Therefore as an education strategy, it requires stepping up the performance of the education system to ensure Māori are enjoying educational success-as Māori. The strategy was designed to concentrate on a transformational shift in the performance of the education system with Māori. Ka Hikitia takes an evidence-based, outcomes-focussed Māori potential approach, and is wholly premised on the notions of "realising Māori potential" within collective responsibility. Fundamentally, the strategy required all those 
involved in education to make an attitudinal (or paradigm) shift-from a perspective targetting potential and opportunity. Threaded throughout Ka Hikitia is the inherent value of "culture", with a clearly articulated strategy that "culture counts" as a key driver (Bishop \& Glynn, 1999; Penetito, 2006).

Culture and education are inextricably interwoven, in the education system as well as in the learning setting. Māori children and students are more likely to achieve when they see themselves, their whānau, hapū and iwi reflected in the teaching context and environment, and are able to be 'Māori' in all learning contexts. The New Zealand Curriculum provides further opportunities to realise this by enabling schools to decide much of the content of, and contexts for, learning. (Ministry of Education, 2008, p. 20)

Ka Hikitia clearly stipulates the need for educational leaders to act on the evidence about what "works best for Māori"; actively practice and advocate the strategy approaches; value culture; and be more accountable for Māori educational outcomes. One crucial point that needs to be understood is the significance of 'culture' itself-which includes identity and community. So, what is 'culture'? Durie (2001) declares that "culture is a convenient way of describing the ways members of a group understand each other and communicate that understanding" (p. 4).

Nuthall (2001) highlights the challenge of recognising what culture is by suggesting that as culture becomes so much a part of who we are, we may inadvertently become blind to what it essentially is, or actually represents.

\section{Striding on from Ka Hikitia: Managing for success}

In recent years a suite of Aotearoa New Zealand research studies on culturally effective practices in many classrooms has found that Māori students achieve and retain at higher levels, are more motivated, and develop more positive attitudes when they learn through collaborative and supportive processes. In contexts where these processes prevail, the wellbeing of the group is foremost and active engagement in the co-construction of learning exists (Alton-Lee, 2003; Harris, 2007; Kay, 2008; Prochnow \& Macfarlane, 2008). Regardless of the research methods adopted, the sample size or the regions studied, three powerful overarching strands of findings have emerged. First, most Māori students learn best when relationships-based teaching is implemented (Cavanagh et al., 2012; A. Macfarlane, 2007; Pere, 1982). This approach is collective, supportive, genuinely reciprocal and provides the learner with elements of choice. Second, there is a correlation between the learning content and context, and students' cultural identity - in other words, students see relevance in, and have a connectedness to, the curriculum activities within a culturally inclusive environment (A. Macfarlane, 2004; A. Macfarlane, S. Macfarlane, \& Gillon, 2014; Manning et al., 2011; Nuthall, 1997). Third, the building and maintenance of positive relationships amongst teachers and students is given paramount attention (Bishop et al., 2007).

Teachers can make a difference in young people's lives-so much so that teachers' attitudes and skills need to be constantly reflected on, reviewed, and reassessed on the basis of new research, strategies, policies and systems (Hattie, 2003). Critical notions relating to whole-school and classroom culture, for example, continually need to be considered (Fiedler et al., 2008), especially to understand the impact of culture on teachers' teaching and students' learning, and the use of culturally responsive practices. These impacting imperatives are endorsed by additional New Zealand studies (A. Macfarlane, 2004, 2007; A. Macfarlane, Glynn, Grace, Penetito, \& Bateman, 2008; Prochnow \& Macfarlane, 2011) which report on culturally responsive teaching and learning strategies specific to Māori students, and offer profiles of what this looks like in action. The congruencies between these and similar international studies (Au, 1998; Darling-Hammond, 2010; Ladson-Billings, 1994; Sagor, 2003; Sleeter et al., 2005; Stanford, 1997) are too marked to be mere coincidence. What these teachers did in their classrooms and how they infused elements of sensitivity and sensibility into their practice were what made a difference for their students in terms of their motivation and learning.

Culturally responsive pedagogy has a multitude of layers. It requires teachers to approach the practice of teaching as a moral craft—an approach that effectively brings into play the heart, the head and the 
hand (Sergiovanni, 1994). The heart is about adopting a philosophy which incorporates beliefs, values and vision. The head involves personal or cognitive theory. The hand is about practices - the skills, strategies and decisions. Culturally responsive pedagogy is premised on creating a 'culture of care' and warmth in the classroom; one that accepts each member of the class making them (including the teacher) feel that they are a valued member (whānau) where everyone's strengths contribute to and provides benefit for collective and individual learning. Creating a culture of care requires implementing the concept of manaakitanga - which has a centrality in the Māori world (Cavanagh et al., 2012).

Culturally responsive pedagogy enables Māori students to feel secure with their own identities in school (A. Macfarlane, Cavanagh, Glynn, \& Bateman, 2007; A. Macfarlane, Webber, et al., 2014). This can be effected through making learning experiences more personally meaningful; engaging them in activities that relate to their interests and experiences outside of school; utilising materials and iconography presented in an authentic manner; including relevant content in culturally familiar social contexts; and improving community involvement in learning by promoting stronger connections among schools, parents and the community (A. Macfarlane, Webber, 2014).

\section{Ka Awatea: The emergence of light}

This section of the paper reports on a research project carried out in eight secondary schools in a provincial city in Aotearoa New Zealand. A Te Arawa iwi-based research consortium initiated a pilot study in 2008, followed by a two-year research project (2012-2014). The focus of the project was to explore and describe the key dynamics that are expressed by high-achieving Māori students in their final year (Year 13) of compulsory schooling, so as to extend our understanding of Māori students' educational success (A. Macfarlane, Webber, 2014). The consortium was focussed on identifying the reasons for their high-achieving students accomplishing educational success. The methodology and its analytic process in this study were guided by Kaupapa Māori phenomenology. Kana and Tamatea (2006) maintain that Kaupapa Māori phenomenology as a research framework attends to unpacking and meaning-making of cultural events, narratives and conditions. Grounded in Te Arawatanga (Emery, Worrall, \& Tahana, 2011), this project surveyed 66 educationally successful senior Māori students (aged 17 and 18 years), 38 teachers, five school principals, 29 whānau, and others involved in the core of the nested system of schooling. The students were chosen by their schools for the positive qualities and attitudes they possessed and their educational success. In addition, the collection of data was cast wider to include the thoughts and realities of pakeke (those more mature participants whose perceptions aligned with that invaluable and immeasurable quality-wisdom), and tuakana (those in mid-career who were climbing toward a tihi or zenith in their respective pathways).

A questionnaire, one-to-one interviews, focus group discussions and conversational interactions (the latter three audiotaped and transcribed) were used to explore participants' perceptions and constructed meanings related to secondary school educational success. After the questionnaire and transcriptions were analysed using thematic analysis (phase 1) (Braun \& Clark, 2006), the detected themes were then scrutinised for possible links to a unique rauemi (survey instrument) (Phase 2), created by the research consortium prior to the research. This rauemi framework comprised eight 'success' attributes that were reflective of eight individual, highly skilled tribal ancestors respected for their leadership. The eight identified attributes were identity, diligence, relationships, innovation, wellbeing, scholarship, humility and values. Following both of the analysis phases, feedback from the stakeholder groups was compared to determine areas of agreement and divergence. The triangulation of the data in this way, using different sources of information, increased the validity of the study.

The idea of embarking on this research project to explore the challenges and promises of Māori students succeeding at school had its genesis in 2008 with a community of Te Arawa educators whose shared ideology was predicated on serving the iwi by way of research-related activities. Like all iwi (tribes) in Aotearoa New Zealand, Te Arawa place high importance and value on young people's learning. The desire for educational success in the younger generations has been paramount to the growth and development of the land and people-those of today, and those not yet born. Notwithstanding the national statistics, there are growing numbers of Māori students doing well at 
school, alongside constant calls for changes to school environments, communities and curricula that assure sustained Māori success. This study was about making culture count.

Within a 'culture counts' context such as this, the 'Ka Awatea' project recognised the altruistic history of Te Arawa educational provision, and acknowledged the foundation that was set down by tribal ancestors for the benefit of those who followed them. The references to the past had great importance to the study, made more real by identifying the eight 'success' qualities modelled by former Te Arawa icons. This endeavour was embedded in the intention to contribute to the challenges of today's educational terrain by raising an awareness that is located in culture, discourse and history. Our analyses revealed that this intention was of significant value. The ancestral characteristics became key indicators for success within contemporary educational and societal systems.

In this paper, discussion of our findings is only focussed on the identified themes interpreted from thematic analysis. Before doing so, however, it is essential to signal that most of the students in this study stood out because of their desire to learn, their generally positive attitude towards school and their motivation to pursue opportunities post-school that would improve the wellbeing of their whānau. More specifically, the majority of the students had positive self-concepts, positive academic self-efficacy, and were intrinsically motivated by school and most of what it offered. They tended to be goal-oriented and future-focussed. To this end they saw a strong relationship between school and work, and in many instances possible career options.

These students appreciated extra academic support, both in and out of the classroom, and valued contact with their parents and teachers who took a personal interest in them as individuals. They considered that choosing 'like-minded' friends was crucial to their ability to stay focussed at school. Other participants in the research project described these high-achieving students as being resolute and tenacious, and said they were confident or able to encourage or push themselves towards success.

A distinctive overriding theme evolved in an in-depth analysis and interpretation of the data-the construct that Māori refer to as 'mana'. Royal (2006) describes a teacher of mana as one who does not merely impart knowledge but somehow awakens students to deeper possibilities within themselves. The Te Arawa study showed that students with mana do something with the potential that resides within them. Mana tells people that there is more to themselves than themselves. It is about cultural pride, identity and usefulness.

\section{Mana: A driver of Māori students' success}

Remember that you represent your Māori culture—do so with pride.

I want to make them proud of the strengths I have. I must get a good education-whai ngā tapuwae o ngā tūpuna (follow the footsteps of your ancestors).

Be dedicated — put your all into everything you do. Be determined—strive to achieve your goals. Be disciplined-discipline yourself to stay focussed on tasks.

(Macfarlane, Webber, et al., 2014, p. 67)

These quotes from students signal the concept of mana — cultural pride, identity and usefulness.

Located within this overriding theme of mana, four major mātauranga (educational) replenishing themes (sub-themes) emerged as strong 'ingredients' for Māori students to achieve educational success. These were motuhake, tū, ūkaipō and tangatarua. A brief description of each theme follows.

Interestingly, along with the four Mana themes, the study revealed an overarching 'lever' that affected all of the contributing factors for success - the whannau. The concept of whānau appeared to have no bounds - regularly visible throughout the study, rendering it a priceless presence. It is to these themes and overarching 'lever' that we now turn.

Mana Motuhake, refers to a positive sense of Māori identity and according to this study is crucial if Māori students are expected to succeed. It is experienced via developing a sense of cultural efficacyby students knowing they can engage meaningfully in school life when their learning is motivated by Māori values such as manaakitanga (an ethic of care) and māhaki (an ethic of humility). Successful 
Māori students in the study were more likely to experience a sense of belonging and connectedness to others in their whānau, school and community. Whānau played a most important role in terms of socialising their youngsters into the Māori world and helping them to develop cultural efficacy.

Research indicates that many schools do not play as important a role in enabling Māori identity to be developed, apart from those instrumental teachers who purposefully engage with Māori students around kapa haka, Māori studies and te reo Māori (Bishop \& Berryman, 2006; Glynn et al., 2005). The Ka Awatea study endorsed this, adding that Māori communities tend to see young Māori as critical players in the continuation of Māori culture, language and tradition. They like to see their students equipped to play a meaningful and successful role in social and cultural activities.

Mana Tu refers to a sense of courage and resilience, the second quality considered critical for Māori students to achieve at school. The study found that successful students develop positive self-efficacy and self-concept, courage, resilience and an internal locus of control to thrive in the school context and eventually beyond it. They tended to be aspirational, have high expectations and enjoy overall physical, emotional and spiritual wellbeing.

Mana tū is more likely to occur when whānau ensure their children have a healthy home environment that supports their physical, emotional and spiritual wellbeing. In this environment whānau members model practical resilience strategies - for example work ethic, perseverance, determination and discipline-because students look to whānau as their "first teachers" and ultimate "motivation for success".

Mana tū is also brought about by "touchstone teachers" who act as mentors and as confidantes at school. These teachers look for the good in students, articulate Māori students' potential and have high expectations of them. Successful Māori students saw themselves as contributing community members. They wanted the community to provide opportunities for them to meaningfully participate in the broader success of their whānau, hapū and iwi communities.

Mana Ükaipo refers to the learning environment offering a sense of place and making the learning relative to the context. This had a centrality for Māori students as they sought a synergy between school-based learning and the unique district (rohe) context-referred to as place-based learning. They wanted to see successful Te Arawa as role models made visible and prominent in schools. Te Arawa students wanted tribal heritage to have some resonance with their educational activities, and expected this heritage to occupy a position of importance in the school curriculum in the rohe. They perceived tribal connectedness to be a viable platform for future aspirations and achievement.

Mana Tangatarua refers to students valuing bi-education-a sense of navigating success in two worlds. All participants considered bi-identities as vital to overall 'success'. Academic success should not come at the expense of Māori identity. However, students need appropriate 'navigational skills' and 'role models', and a strong sense of emotional and spiritual wellbeing to traverse the two worlds of Māori and tauiwi (people of other ethnicities) successfully.

Participants' responses indicated that encouraging and galvanic relationships are essential to success. Families are primarily responsible for "success as Māori" and should model what this looks like. Schools contribute largely to Māori students' "success in the non-Māori or 'generalist' world" because they offer students many opportunities to be innovative, creative, try new tasks or activities and take risks. Many Māori families cannot offer these opportunities and value education for doing so. Therefore, schools can offer students new experiences that "unleash their potential" to bridge their two worlds and increase their "range of opportunities" in terms of "possible futures".

While schools play a role in students' physical wellbeing, they appear to contribute minimally to Māori students' emotional wellbeing. The study showed that the wider Te Arawa community wanted Māori students to thrive in the non-Māori world but retain "a heart for things Māori” within proximity to the tribe - the 'culturalist' world. All participants valued the reciprocal role that successful Māori will play in terms of eventually "coming home to make a difference", "participating in the ongoing success of others" and "giving back" to their whānau and communities. 


\section{The overarching lever: Mana Whānau}

The study signalled that successful Māori students inhabited a central position of importance within their whānau. They were nurtured into succeeding in both worlds by their whānau, were socially capable and had a developing sense of belonging within a range of contexts. Successful Māori students appreciated that their families valued education, and that their school success was important to the whole whānau - because their success is considered as whānau success. The converse applies to failure. As a consequence, successful Māori students have a fear of not reaching their potential and letting their whānau down. In the final analysis successful Māori students take the responsibility of 'academic success' very seriously.

The four themes and overarching lever are key reference points in the development of a 'Ka Awatea Mana Conceptual Model' for educational success. The model espouses ancient wisdom and ways of knowing as well as ways of communicating sets of skills to others. These skills might rightly be referred to as cultural assets because they enable Māori learners and teachers of Māori learners to address the achievement discrepancies by unleashing potentialities.

If education is about successful learning and development then it must also be about enhancing cultural continuity and growth. The continuity culminated with the development of a conceptual model (see Macfarlane, Webber, et al., 2014, p. 177), a unique trajectory of Māori knowledge which upholds a theory that education and culture grow out of the past, function in the present, and hold hope for the future.

\section{Conclusion}

It has been clear for a long time and in many countries just how poorly many conventional education systems have served Indigenous students. Much of what was once considered fair, right and just in the provision of education may no longer be deemed principled, relevant or appropriate. Recent developments continue to reshape the landscape of provision for minoritised students (those from minority cultures), and while there is much to be applauded, concerns still linger. As an evolving society, educators are continually reflecting on the events and experiences of the past, taking stock of the issues and realities of the present, and then adapting the parameters, definitions and constructs that serve to define acceptability and reason as steps are made into the future. This paper maintained a focus on a rationalisation that is concerned with how greater awareness and knowledge of cultural imperatives can bring about better understandings of context and content, and ultimately, practices that are more attuned to the worldview of minoritised learners.

This paper has proposed that building learning and teaching contexts that are empowering and motivating for minoritised students involves discerningly selecting classic studies from yesteryear and checking their connections to new generation thinkers and writers. The early sections of this paper attempted to cover that. It also involves an intricate examination of nationally mandated policies, strategies and chronicled reports of both effective and ineffective school practices. These are often a platform to uncover and dismantle constructs of optimism, or conversely, inertia. The middle sections of this paper attempted to cover that. Inevitably, however, attention is drawn to the phenomena that drive minoritised students to succeed in systems that may not be designed to accommodate sociocultural epistemologies. In that regard models of resilience and affirmation demonstrated a focus on the qualities that students and their environment possess that enable them to survive and thrive, and thus focus on the assets that lead to positive outcomes. Rather than focus on deficits, affirmative researc studies referred to in this paper focus on questions such as, What is it about these youngsters that drives them? What makes them apparently immune to the factors that negatively affect others? What is the part of schools, families and communities in helping to grow culturally linked socialisation patterns for improved motivation and learning? The answers are elusive, but point to developing a critical consciousness that call for a simple yet profound repositioning of the emphasisa shift toward culturally responsive practice. 


\section{References}

Airini, C., McNaughton, S., Langley, J., \& Sauni, P. (2007). What educational reform means: Lessons from teachers, research and policy working together for student success. Journal of Educational Research for Policy and Practice, 6, 31-54.

Alton-Lee, A. (2003). Quality teaching for diverse students in schooling: Best evidence synthesis. Wellington, New Zealand: Ministry of Education. Retrieved from www.minedu.govt.nz/goto/bestevidencesynthesis

$\mathrm{Au}, \mathrm{K} . \mathrm{H}$. (1998). Social constructivism and the school literacy learning of students of diverse backgrounds. Journal of Literacy Research, 30(2), 297-319.

Bishop, R., \& Berryman, M. (2006). Culture speaks: Cultural relationships \& classroom learning. Wellington, New Zealand: Huia.

Bishop, R., Berryman, M., Cavanagh, T., \& Teddy, 1. (2007). Te Kotahitanga Phase 3: Establishing a culturally responsive pedagogy of relations in mainstream secondary school classrooms. Report to the Ministry of Education. Wellington, New Zealand: Ministry of Education.

Bishop, R., \& Glynn, T. (1999). Culture counts: Changing power relations in education. Palmerston North, New Zealand: Dunmore.

Braun, V., \& Clarke, V. (2006). Using thematic analysis in psychology. Qualitative Research in Psychology, 3(2), 77-101.

Brayboy, B. M. J. \& Castagno, A. E. (2009). Self-determination through self-education: Culturally responsive schooling for indigenous students in the USA. Teaching Education, 20(1), 31-53.

Cavanagh, T., Macfarlane, A., Glynn, T., \& Macfarlane, S. (2012). Creating peaceful and effective schools through a culture of care. Discourse: Studies in the Cultural Politics of Education, $33(3), 443-455$.

Darling-Hammond, L. (2010). The flat world and education: How America's commitment to equity will determine our future. Columbia University, NY: Teachers College Press.

Delpit, L.D. (2006). Lessons from teachers. Journal of Teacher Education, 57(3), 220-231.

Durie, M. (2001, November). Cultural competence and medical practice in New Zealand. Paper presented at the Australian and New Zealand Boards and Council Conference, Wellington, New Zealand.

Eisner, E. W. (1994) Cognition and curriculum reconsidered (2nd ed.). New York, NY: Teachers College Press.

Emery, T., Worrall, T., \& Tahana, T. (2011). Te Arawa Research and Development Strategy. Rotorua, New Zealand: Te Arawa Lakes Trust.

Fiedler, C. R., Chiang, B., Van Haren, B., Jorgensen, J., Halberg, S., \& Boreson, L. (2008). Culturally responsive practices in schools: A checklist to address disproportionality in Special Education. TEACHING Exceptional Children, 40(5), 52-59.

Franklin, B. (Ed.). (1998). When children don't learn: Student failure and the culture of teaching. New York, NY: Teacher College, Columbia University.

Glynn, T., Wearmouth, J., \& Berryman, M. (2005). Supporting students with literacy difficulties: A responsive approach. London, England: McGraw-Hill.

Graybill, S. W. (1997). Questions of race and culture: How they relate to the classroom for African American students. Clearing House, 70, 311-319.

Green, V. A., \& Cherrington, S. (Eds.). (2010). Delving into diversity: An international exploration of issues of diversity in education. Hauppauge, NY: Nova Science Publishers.

Harris, F. (2007). (Re)-Constructing Māori children as achieving learners (Unpublished doctoral thesis). University of Canterbury, Christchurch, New Zealand.

Hattie, J. (2003, October). Teachers make a difference: What is the research evidence? Paper presented at the Australian Council for Educational Research Annual Conference, Carlton Crest Hotel, Melbourne, Australia.

Howard, T. C. (2003). Culturally relevant pedagogy: Ingredients for critical teacher reflection. Theory into practice, 42, 195-202.

Kana, F., \& Tamatea, K. (2006). Sharing, listening, learning and developing understandings of kaupapa Māori research by engaging with two Māori communities involved in education. Waikato Journal of Education, 12, 9-20. 
Kay, J. (2008). Listening to the voices of Year 13 Māori students (Unpublished Masters thesis). University of Waikato. Hamilton, New Zealand.

Ladson-Billings, G. (1994). What we can learn from multicultural education research. Education Leadership, 51(8), 22-26.

Ladson-Billings, G. (1995). Toward a theory of culturally relevant pedagogy. American Educational Research Journal, 32(3), 465-491.

Macfarlane, A. (2004). Kia hiwa rāa: Listen to culture-Māori students' plea to educators. Wellington, New Zealand: New Zealand Council for Educational Research.

Macfarlane. A. (2007). In search of a culturally-inclusive curriculum. Reading Forum NZ, 22(1), 2933.

Macfarlane, S. (2009). Te Pikinga ki Runga: Raising possibilities. SET: Research information for teachers, 2009(2), 42-50.

Macfarlane, A., Cavanagh, T., Glynn, T., \& Bateman, S. (2007). Creating culturally safe schools for Māori students. The Australian Journal of Indigenous Education, 36, 65-76.

Macfarlane, A, Glynn, T., Grace, W., Penetito, W., \& Bateman, S. (2008). Indigenous epistemology in a national curriculum framework? Ethnicities, 8(1), 102-126.

Macfarlane, A., Macfarlane, S., \& Gillon, G. (2014). Inclusion, disability and culture: The nexus of potential and opportunity for policy development. In M. Morton (Ed.), Tales from school: Learning disability and state education after administrative reform (pp. 255-270). Rotterdam, The Netherlands: Sense.

Macfarlane, A. H., Webber, M., Cookson-Cox, C., \& McRae, H. (2014). Ka Awatea: An iwi case study of Māori students' success. Report prepared for Ngā Pae o te Māramatanga. Christchurch, New Zealand: Te Rū Rangahau, College of Education, University of Canterbury.

Manning, R. F., Macfarlane, A. H., Skerrett, M., Cooper, G., Andreotti, V., \& Emery, T. (2011). A new net to go fishing: Messages from international evidence based research and kaupapa Māori research. The Australian Journal of Indigenous Education, 40, 92-101.

Medcalf, J., Rangi, C., Macfarlane, A. H., \& Glynn, T. (2003). The reality of culture in the development of a national special education training initiative. He Puna Kōrero: Journal of Mãori and Pacific Development, 4(2), 100-113.

Metge, J., \& Kinloch, P. (1984). Talking past each other: Problems of cross-cultural communication. Wellington, New Zealand: Victoria University Press.

Ministry of Education. (2008). Ka Hikitia: Managing for success-Māori education strategy 20082012. Wellington, New Zealand: Author.

Moore, D., Anderson, A., Timperley, H., Glynn, T., Macfarlane, A., Brown, D., \& Thomson, C. (1999). Caught between stories: Special education in New Zealand. Wellington, New Zealand: New Zealand Council for Educational Research.

Nuthall, G. A. (1997). Understanding student thinking and learning in classrooms. In B. J. Biddle, T. L. Good, \& J. F. Goodson (Eds.), The international handbook of teachers and teaching (pp. 681-768). Dordrecht, The Netherlands: Kluwer.

Nuthall, G. A. (2001, December). The cultural myths and realities of teaching and learning. Paper presented at the New Zealand Association for Research in Education (NZARE) Conference, Christchurch, New Zealand.

Otrel-Cass, K., Cowie, B., \& Glynn, T. (2009). Connecting science teachers with their Māori students: Linking one school's tuata with forest ecology. SET: Research Information for Teachers, $2009(2), 35-41$.

Parsons, J. (2012). Conversational pedagogies and the gift of diversity. Encounter: Education for Meaning and Social Justice, 25(4), 41-44.

Peer, L., \& Reid, G. (Eds.). (2000). Multilingualism, literacy and dyslexia. A challenge for educators. London, England: David Fulton.

Penetito, W. (2006). Ka Hikitia: A step up in system performance for Māori education. Unpublished paper prepared for the Ministry of Education, New Zealand.

Pere, R. (1982). Ako: Concepts and learning in the Mãori tradition. Hamilton, New Zealand: Waikato University Department of Sociology.

Peters, S., \& Paki, V. (2012, August). Rurea, taitea, kia toitu, ko taikaka anake-Strip away the bark, expose the heartwood, get to the heart of the matter: Examining pedagogical approaches 
and children's learning journeys. Paper presented at the 22nd European Early Childhood Education Research Association (EECERA) Annual Conference, Oporto, Portugal.

Pierce, C. (1996). The importance of classroom climate for at-risk learners. SET special: Students at risk, item 10.

Prochnow, J. E. (2006). Barriers toward including students with difficult behaviour in regular classrooms. New Zealand Journal of Educational Studies, 41(2), 329-347.

Prochnow, J., \& Macfarlane, A. (2008, August). Managing classroom behaviour: Assertiveness and warmth. Paper presented at the 1st Educational Psychology Forum, Faculty of Education, University of Auckland, New Zealand.

Prochnow, J., \& Macfarlane, A. (2011). Managing classroom behaviour. In C. Rubie-Davies (Ed.), Educational psychology: Concepts, research and challenges (pp. 150-166). London, England: Routledge.

Royal, T. A. C. (2006, September). A modern view of mana. Keynote address at the Joint Conference of the Australian Psychological Society and the New Zealand Psychological Society, Auckland, New Zealand.

Sagor, R. (2003). Motivating students and teachers in an era of standards. Alexandria, VA: ASCD.

Savage, C., Hindle, R., Meyer, L., Hynds, A., Penetito, W., \& Sleeter, C. (2011). Culturally responsive pedagogies in the classroom: Indigenous student experiences across the curriculum. AsiaPacific Journal of Teacher Education, 39(3), 183-198.

Sergiovanni, T. J. (1994). Building community in schools. San Francisco, CA: Jossey-Bass.

Sleeter, C. (2001). Preparing teachers for culturally diverse schools: Research and the overwhelming presence of whiteness. Journal of Teacher Education, 52, 94-106.

Sleeter, C., Hughes, B., Meador, E., Whang, P., Rogers, L., \& Blackwall, K. (2005). Working an academically rigorous, multicultural program. Equity and Excellence, 38(4), 290-298.

Smith, D. G. (2009). Diversity's promise for higher education: Making it work. Baltimore, MA: John Hopkins University Press.

Stanford, G. C. (1997). Successful pedagogy in urban schools: Perspectives of four African American teachers. Journal of Education of Students Placed at Risk, 2(2), 107-119.

Starnes, B. (2006). What we don't know can hurt them: White teachers, Indian children. Phi Delta Kappan, 87(5), 384-392.

Telford, M., \& Caygill, R. (2007). PISA 2006: How ready are our 15-year-olds for tomorrow's world? Wellington, New Zealand: Education Counts. Retrieved from http://www.educationcounts.govt.nz/publications/series/2543/pisa 2006

Townsend, B. L. (2000). The disproportionate discipline of African American learners: Reducing school suspensions and expulsions. Exceptional Children, 66, 381-391.

Wheldall, K., \& Glynn, T. (1989). Effective classroom learning: A behavioural interactionist approach to teaching. Oxford, England: Basil Blackwell.

Ysseldyke, J., \& Christensen, S. (1998). TIES II: The instructional environmental system-II (4th ed.). Longmont, CO: Sopris West. 